\title{
The nation, the state, and the neighbors: personation in Irish-language discourse
}

\author{
Steve Coleman * \\ Department of Anthropology/NIRSA, National University of Ireland Maynooth, Co. Kildare, Ireland, \\ and Humanities Institute of Ireland, University College, Dublin, Ireland
}

\begin{abstract}
Irish-language discourse features a pervasive system of practices involving the production and dissemination of directly reported speech. These homologous practices, here termed personation, include brief imitations of others in conversational speech, the use of direct voice in several poetic genres, the Irish-language song tradition, and a few influential novels. Personation is motivated by a semiotic ideology (personalism) which naturalizes speech and other expressive behavior as an immediate aspect of a person's social being. It is argued that personation, as a semiotic practice, motivates Irish-speakers' resistance to various attempts, centered in discourses of the nation and the state, to refigure the Irish language as the "voice" of a generalized and purified national past or as a semiotically transparent medium for the state.
\end{abstract}

(C) 2004 Elsevier Ltd. All rights reserved.

\section{Introduction}

This paper examines a range of speaking and textual practices in Irish-language discourse, focussing in particular on those which are motivated by a semiotic ideology (Keane, 2003), here termed "personalism", which valorizes certain types of transposed utterance (Haviland, 1996) as bearing traces of the particular past, of specific local persons, and socially sanctioned "traditional" perspectives. These practices and ideologies contrast with others which valorize Irish-language discourse as rooted in a generalized pre-colonial past, or as a modern vehicle of state. Personalist discourse, while not confined to rural (typically marginalized) communities,

\footnotetext{
*Fax: +353-1-708-3570.

E-mail address: scoleman@may.ie (S. Coleman).
} 
is particularly prevalent among speakers who have social and personal connections to these communities.

I argue that personation is a metapragmatic practice featuring the creation of utterance (or other communicative action such as dance and musical style) explicitly or implicitly voiced as that of another. Personation occurs on its own, but also, I argue, informs the production and reception of a variety of communicative genres. These genres, and the valorisation of specific personal "voice" that they underwrite, are used as a resource by speakers in their resistance to certain practices and ideologies aligned with conservative nationalism (the voice of the archaic "nation") and to modernizing "state" discourses.

\section{Contemporary situation of Irish}

Irish is recognized, along with English, as an official language of the Irish State, but its social role and status conform to that of a minority language in Romaine's (1994) sense. These anomalous social positions motivate a range of often conflicting ideological constructs, in which Irish is seen simultaneously as "the language of all" (it is a mandatory subject in primary and secondary education) and as "the language of some" (it is spoken regularly only by a small minority). As "the language of some", Irish is popularly represented either as the "state speech" (cf. Errington, 1995) of urban elites or else as the vanishing language of a group of typically poor, rural speakers. Since 1926, the Irish state has recognized certain geographical districts on the rural periphery as "Irish speaking areas" (An Ghaeltacht), making them a focus of development projects aimed at preservation of the language. The most basic and emblematic state practice in this regard is the small annual grant to Gaeltacht families whose school-age children are certified as competent Irish speakers.

The multiple sites and social positions of Irish are reflected only indirectly in census data. Table 1 indicates responses to a census question asking how often they and their children speak Irish.

As "daily speakers", school-age children predominate in the state as a whole, reflecting the almost entirely educational role of Irish in everyday life. In the Gaeltacht regions, Irish has a more extensive role, but its "daily use" is statistically weak for all age groups, especially among young people just out of school. Data like these are highly misleading, however, since the position of Irish was never strong in many areas classified as "Gaeltachtaí". Like the state as a whole, Gaeltacht regions feature networks of speakers who habitually use Irish in most domains, including the home, as well as networks of speakers who tend to only use Irish in more restricted domains. It is also likely that the majority of native speakers of Irish, even those from Gaeltacht backgrounds, live in urban areas, especially in the capital, Dublin.

State policy has tended to locate Irish speakers geographically rather than tackle difficult questions about bilingualism and the question of what constitutes an "Irish speaker'. In what Ó Ciosáin (1991, p. 7) calls 'the geographic fallacy', the Gaeltacht is defined in terms of physical space, rather than in terms of community structure or 
Table 1

"Daily Speakers of Irish" within the state as a whole and within the officially recognized Gaeltacht

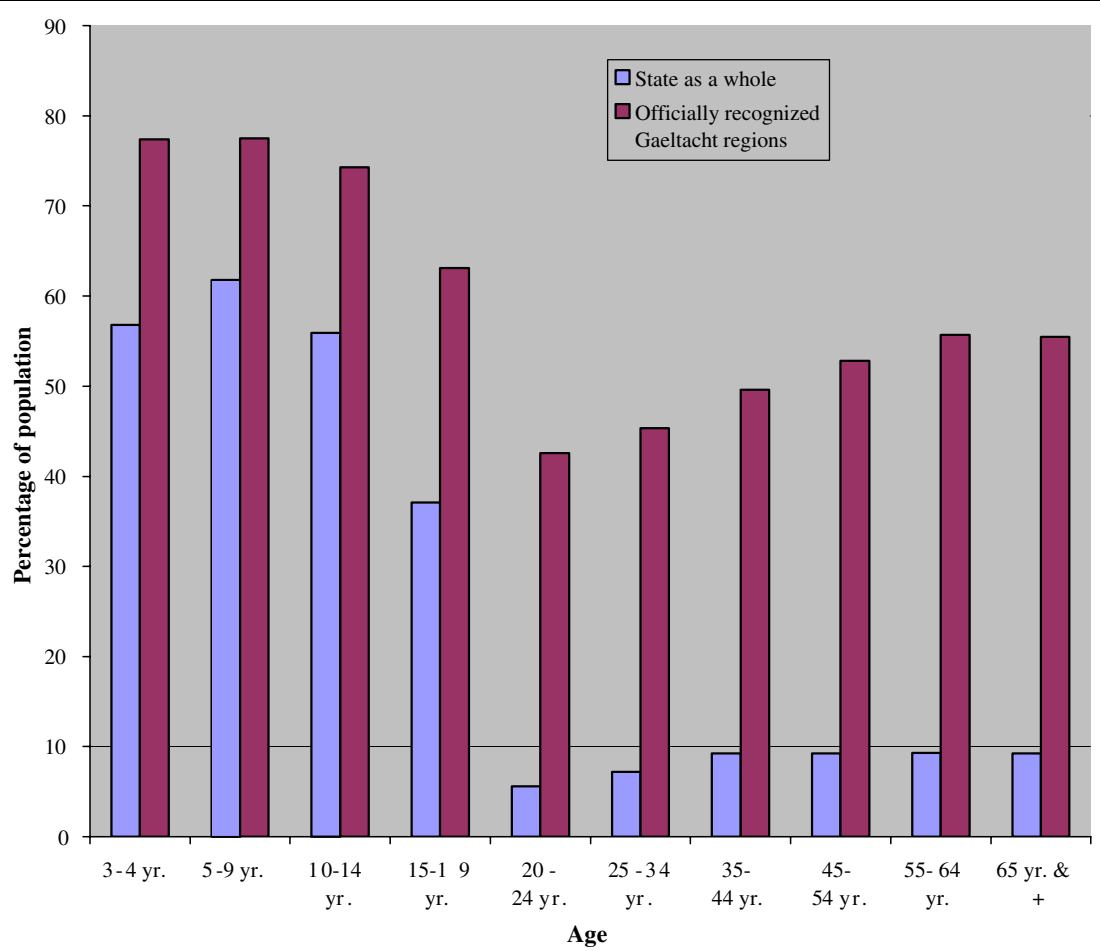

(Source: Coimisiún na Gaeltachta, 2002, data from Census of Ireland, 1996).

language use. This suits the bureaucratic logic of the state, while facilitating an ideological role for the Gaeltacht as a "heartland" or "treasure" of national identity (Ó Giolláin, 2000). It has also led to a situation where, until very recently, ${ }^{1}$ the state has not recognized the rights of Irish speakers outside of the Gaeltacht, nor has it acknowledged the habitual use of Irish as a marker of any distinctive ethnic or cultural identity within the Irish nation.

\section{The nation, the state, and the neighbors}

Semiotic ideologies pertaining to Irish have primarily taken the form of three major discourses, which I here term the discourse of "the state" (advocacy of

\footnotetext{
${ }^{1}$ A "language bill" has passed the Dáil (Irish parliament) which includes reference to the linguistic rights of Irish speakers, but without clear provision as to how these rights would be enforced.
} 
standardizing Irish as a form of linguistic modernization), the discourse of "the nation" (a purist conservatism), and the discourse of "the neighbors" (linguistic personalism). The first two discourses operate in what could be called the "national" arena, positing ideal relationships between language, the speaking subject, and the state. The discourse of personalism operates mainly among speakers influenced by the linguistic culture of the Gaeltacht. It also posits relationships between language, the speaking subject, and community, but is in many ways opposed to the first two discourses, and often involves a rejection of the state and state-defined notions of linguistic propriety. Any individual, whether of Gaeltacht or non-Gaeltacht origins, can participate in any or all of these discourses, even within a single statement.

Discussions of standardization inevitably become entangled with dilemmas based on the practices and ideology of the nation-state. These debates raise a deeper ideological issue. Any standardized form of Irish would inevitably function as a superposed "high" register, implicitly devaluing "caint na ndaoine" ("the people's speech', i.e., colloquialism) as merely provincial talk. Such a register would in fact occupy much of the same functional ground that English has held, first in the colonial state and then in the new Irish state. Thus, the role of English and the experience of Irish speakers under anglophone domination underlies debates about the standardization of Irish.

Early debates centered on the question of reviving the literary standard of the 17 th century. ${ }^{2}$ Classical Irish, used throughout Gaelic speaking Ireland and Scotland in the period between 1200 and 1650, was a superposed standard register, regimented by bardic schools and grammatical tracts (McManus, 1994, p. 335). It thus, bore some resemblance to modern standard registers in European languages.

The main point of reference for those who advocated a Standard based on 17th century forms was not a bardic text or even a poetic work, but a polemical history of Ireland, Foras Feasa ar Éirinn, written in the 1620 s by a French-educated priest, Geoffrey Keating. The language of Foras Feasa "was to become the linguistic and stylistic lodestar of modern Irish prose, much like Luther's Bible translation had been for German"; unlike Luther's work, Foras Feasa circulated in manuscript form and was "probably the last important book in European literature whose influence and dissemination owed nothing to the printing press" (Leerssen, 1996, p. 274). Although Keating's prose style was more modern than that of the classical bardic register, he drew upon bardic style, e.g., in his use of "runs' of alliterative epithets" (Leerssen, 1996, p. 405) - a style still valued (as cruachaint) in present-day Gaeltacht speech (see below).

The magnetic attraction of Keating's work to 20th century Irish revivalists derived not only from its language but also from its function as a polemical "vindication of Irish civility" in response to English calumny (Kiberd, 1996; Leerssen, 1996). Richard Henebry, writing early in the century, advocated a return to the Irish of Geoffrey Keating, banishing English borrowings and what he termed "Revival Irish", which he accused of being a vehicle for thought which "has been conceived in

\footnotetext{
${ }^{2}$ A survey and discussion of these debates can be found in Ó Háinle (1994).
} 
English and is really a more or less mechanical translation of the mental English original" (quoted in Ó Háinle, 1994, p. 760). Henebry, an instinctive elitist, attacked not only revivalists but also the speech of native speakers themselves as being impure. Colloquial Gaeltacht speech contained many borrowings from English; likewise, many newly created words in popular usage were based on the semantics of English rather than Irish.

\section{Demography, regimentation, and neurosis}

Current-day advocates of standardized Irish seek to ground it in an idiom of modernity rather than in the discourse of the 17 th century. The contemporary argument for a standardized form of Irish has been summarized by Séamas O Murchú:

It is generally accepted now that a standard, especially a written standard, is necessary for Irish if it is to be advanced as a national language. In short, it is needed as: (a) a unifying link between the various dialects and (b) an aid to the learner (Ó Murchú, 1978, p. 362, my translation).

This is the simplest form of the discourse of national development, which sees a need for unifying the forms of Irish in order to unify speaking and reading publics.

However, "a unified Irish language is still only an object to pursue". 3 Any language must acquire new words or add to the range of meaning of existing words as the social, technical, and physical world of its speakers changes. The particular problems facing Irish, as a minority language in a basically anglophone modern nation-state, are particularly intense and bring into relief many typical aspects of European semiotic ideologies. Thus, in the discourse of state development, the hoped-for unity of Irish also requires its semantic completeness - as one person put it to me, Irish needs to have "words for everything".

The idea that a non-standardized Irish is incomplete or incapable of dealing with modern realities is very deeply ingrained. Perhaps ironically, Ó Háinle (1994, p. 777) mentions "a list of 80 words compiled at Yale University in 1962 to test the modernity of languages". Irish lacked only three of them: words for "demography", "regimentation" and "neurosis". But he points out that Ó Dónaill's 1977 IrishEnglish Dictionary gives us déimeagrafaíocht agus néaróis, leaving the Irish language lacking only "regimentation"!

Notice that one does not test for "modernity" by asking if anyone is using Irish to engage with the sorts of things that English-speakers sometimes call "demography", "regimentation", or "neurosis". Rather it is the presence of the "concepts" felt to be embodied in the actual forms of (English) words that is needed, and Ó Dónaill's déimeagrafaíocht and néaróis, being calques or loan translations of the English terms, reassuringly resemble them as well.

\footnotetext{
${ }^{3}$ Madne Oftedal, in a review of De Bhaldraithe's (1959) Irish English Dictionary, quoted in de Bhaldraithe (1992, p. 204).
} 
How is Standard Irish regimented? When Gaeltacht speakers disparage "book Irish", the "book" they refer to might as well be any book, but if we have to choose one, there is The Official Standard: Grammar and Orthography of Irish (An Caighdeán Oifigiúil: Gramadach na Gaeilge agus Litriú na Gaeilge) published by the Irish state in 1958. This book was the latest in a series of government documents which began with spelling reforms in the 1940s when various systems of orthography based more or less on Classical Irish were finally abandoned (Ó Siadhail, 1981, pp. 71-72). As the title suggests, the authors of this work wished only to arrive at a standard spelling and grammar for government publications. At the same time, they hoped that the book would provide guidance to publishers and teachers - in short, that it would give birth to a genuine Standard that would eventually gain wide acceptance. This would make Irish "able to compete with English... [and would keep it] abreast of the languages of other cultured communities" 4 (quoted in Ó Háinle, 1994, p. 783).

This Standard is the creature of the Dáil translation bureau (Rannóg an Aistriúcháin). The first Dáil (the Irish parliamentary body), elected after most of the leaders of the failed 1916 Easter rising were executed by the British, met on January 21st, 1919. Famously, it transacted all its business in Irish (Daltún 1983:13). Subsequent sessions were conducted in both Irish and English, and the translation bureau was created to mediate between the two languages.

A few monolingual Irish speakers were elected to the Dáil in the 1930s, but the great majority of Dáil debate has been in English. Irish and English are constitutionally the "first" and "second" official languages of the state. In practice, laws are drafted, debated and enacted in English, then translated into Irish.

The translation bureau, along with related civil service bureaus and committees, is thereby engaged in a massive effort of linguistic regimentation, motivated by an ideology of referential transparency between the two languages. Thus, the philosophy of the Terminology Committee of the Department of Education:

That as far as possible one term shall express one concept, and one concept shall be expressed by one term; for example in environmental matters that trualliu is the same as 'pollution' and that no other term is recommended but truailliú. ${ }^{5}$

The State functions in English, creating a register of semantically equivalent Irish forms. But the more perfectly this semantic equivalence is achieved, the more this formal register of Irish becomes a calque of its English equivalent. This is the "mechanical translation" that Henebry feared.

Gaeltacht people could thus be forgiven for seeing, in Standard Irish, an Irish language mask covering English-language thought. But this is more or less the way that devotees of Standard see the "creolized" speech of the Gaeltacht. Which is more

\footnotetext{
${ }^{4}$ inniúil ar dhul i gcoimhlint leis an mBéarla... ar chomhrian le teangacha na bpobal cultúrtha eile.

${ }^{5}$ Ó hÓgáin (1983, p. 30); my translation.
} 
"polluted", truailligh, or a word more likely to be heard in the Gaeltacht, "polluteáil’?

In a variant of the "state" discourse of national development Alan Bliss (1981) has advocated establishing three regional standards for Irish, so as not to alienate native speakers. Bliss, like many others, envisions two possible futures for Irish. One option would be to create a Standard Irish which would be used "for all purposes to the exclusion of English." But "if Irish was to be used for all purposes, a standard language would have to be devised ab initio, and a large part of its vocabulary would have to be invented". Bliss admits that has actually been done, but "to use Irish for technical and intellectual purposes is to run counter to the spirit of the times" when English already occupies this position internationally, becoming more and more an international super-standard language (Bliss, 1981, p. 78).

The other option, felt by Bliss to be more realistic, would feature diglossia similar to that of Luxembourg (where French and Luxembourgeois are functionally differentiated). In this scenario, English would occupy the high registers -"used for all scholarly, technical, and political purposes" - with written Irish used only on "a rather small scale - private letters, advertisements, local newspapers and official announcements of a local nature" (Bliss, 1981, p. 78). This writing would be done in the three regional standards. However, documents of national significance like the Constitution would still have to be written in some form of a national standard Irish "which because of its legal force would need to have the same form in all parts of the country" (Bliss, 1981, p. 82). This statement betrays another aspect of the ideology of the standardizing imagination - that legal knowledge comes from the precise wording of laws, rather than from the ongoing deliberations of lawmakers and courts. Interestingly, Bliss does not deal with the question of whether or to what degree the Irish state or any state has defined (or needs to define) an official standard for English (cf. Agha, 2003).

Bliss' argument reveals the greatest vulnerability of the discourse of national development. If one accepts the techno-functionalist view of language (Errington, 1998) implicit in this discourse, one has to admit that the English language is already fulfilling the role hoped for Irish. English-language media and schooling already promote national integration and provide the matrix for a vibrant (and internationally exportable) Irish "national" culture. English also functions as a medium of supranational integration.

Bliss' proposal is in line with the political, economic and linguistic policies of the Irish state. The state has promoted economic growth through encouraging massive direct foreign investment, attracting multinational corporations with extremely low tax rates and the promise of an educated, disciplined, and English speaking labor force. At the same time the state's official language policy has been to promote "bilingualism", although (outside of the educational sector) there is no emergent functional differentiation between Irish and English (Coleman, 2003).

Within Gaeltacht communities the discourse of personalism, backed by an ethic of solidarity, motivates resistance to a superposed Irish-language standard register. This ethos extends, in large part, to the management of Raidio na Gaeltachta (the Irish-language broadcasting service), much to the puzzlement of the linguist Máirtín 
Ó Murchú, who argued that written Standard Irish should be augmented by a spoken standard as well:

When Raidió na Gaeltachta began, a new necessity was felt for standardization of the spoken language so that the speakers would be widely understood, and because they were worried about certain complaints that were being made regarding the quality of the Irish that was broadcast.... [In response] it was argued that it would be 'completely unreasonable to expect anyone of them to speak anything other than their own natural dialect'. This argument seems to reveal a complete disregard for the particular features that obviously pertain to cultivated speech in comparison to ordinary speech in any linguistic community (Ó Murchú, 1984, p. 18, my translation).

The response of the station's management exemplifies the discourse of personalism insofar as it invokes one of the core values of Gaeltacht culture, "nature" (nádúr). But Ó Murchú's objection is equally ideological. He presents the choices available for the language as being to either develop it "as a broad multifunctional aspect of our culture" (mar ghné fhairsing ilfheidhmeach dár gcultúr) or "to leave it bound within the local folklore traditions that have survived this long" (i a fhágáil fuaite laistigh de na traidisiúin áitiúla béaloidis atá tagtha slán chomh fada seo).

This is an example of a discourse of national development applied to the Irish language. It valorizes certain linguistic forms (standard Irish) in terms of their modernity - a modernity which is manifested through orthographic and aural homogeneity. These homogeneities are rationalized in terms of the regimented code's supposed neutrality and semiotic transparency (Silverstein, 1987, 2000; Errington, 1998). Underlying the discourse is a semiotic ideology similar to that of Anderson (1983) in his analysis of the rise of the nation-state: that uniformity of code promotes "wider communication" (an chumarsáid fhorleathan) and the ability "to draw together speakers of the language in a unified community" (lucht labhartha na teanga a dhlúthú i bpobal aontaithe). In contrast, the non-standardized codes of the peripheries are seen as narrowly traditional, "local" - i.e., bound to specific places and persons, and old-fashioned.

The ideology of standardization tends to elide issues of domination of the peripheries by the center, attributing the power of the center to the inherent linguistic qualities of the rationalized code. In the Gaeltacht, however, speakers tend to explicitly respond to Standard Irish forms in terms of power and symbolic domination, reading these forms in terms of their provenance in the rituals of power of the centralized state (see below).

\section{Speaking for and from "the nation": a discourse of linguistic purity}

The set of discourses which I label "the nation" bear a close relationship to that of personalism in that they explicitly ground linguistic value in the speech of 
particular communities - the "living speech of the Gaeltacht". But parallel to the discourse of "the state" discussed above, the discourse of "the nation" is forced by its own ideological contradictions into a position which condemns the actual speech of Gaeltacht communities as hopelessly impure. It ends up idealizing a more or less non-existent purity, spatially located far away on the cultural and linguistic peripheries of the nation-state and temporally located in an indefinite past of "tradition". It thus combines, often uneasily, a highly particularistic view of proper Irish speech as strictly localized, with an ideological point of view that sees local communities from the outside, as representatives of a generalized past.

At the turn of the century, the writer and activist Father Peadar Ua Laoghaire argued that a return to classical Irish would devalue the living speech of the Gaeltacht and advocated sticking to "caint na ndaoine". Those who advocated sticking to the "living speech of the Gaeltacht" sometimes went as far as advocating not standardizing Irish at all, or developing three regional standards rather than one national standard. Ua Laoghaire represented one extreme in the debate:

The man who wants to 'avoid provincialisms' simply avoids the language. Hence, what he writes is not Irish of any description. It is simply a Volapük invented by himself. [...] The proper thing to do is to preserve carefully all 'provincialisms': not to let a shred or a trace of them be lost. [...] Let us preserve, not only 'provincialisms', but even the most isolated localisms. Ink and paper are not very expensive (quoted in Ó Háinle [1994, p. 761]; Ua Laoghaire's emphasis).

A 1954 article by the poet Seán Ó Ríordáin exemplifies the relationship between the discourse of "the nation" and linguistic purism. Ó Ríordáin was a native speaker of Irish from Baile Mhúirne in Co. Cork, a Gaeltacht area which he describes as being breac go maith ("very spotty", i.e., going over to English) during his youth. Later in his life he visited Corca Dhuibhne on the Dingle peninsula in Co. Kerry and was impressed by the "purity" (glaine) of the dialect there. He compares this in the article to the dialect of Sophocles and Plato, dubbed "exquisite parochial" by Arnold Toynbee. He quotes Gerard Manley Hopkins's lament for "what Anglo-Saxon might have been" as a literary language if it had escaped "mixture" with other languages. In Hopkins' words, "in spite of all that Shakespeare and Milton have done with the compound I cannot doubt that no beauty in a language can make up for want of purity". Ó Ríordáin comments that such purity depends on "dialects being separated from one another as they are now. The more separate they are, the purer, the more closely knit, the more native they are". Here, Ó Ríordáin takes the "separation" of the dialects, the historical effect of the decline of Irish, and makes it into a virtue.

Ó Ríordáin continues with a suggestion that when the language is revived and spreads throughout Ireland, it would be better for one dialect to gain the upper hand than for all the dialects to meld together. He then gives advice to gaeilgeoiri (Irish-learners) who wish to gain access to the "beauty" (áilleacht) of a specific local dialect: 
Say it is an urban Gaeilgeoir who seeks it. He must live in the Gaeltacht for at least a year and be humble in his mind in the presence of the people. He must hold in contempt whatever Irish he still remembers throw away whatever he has. He must be reborn. He must let the living Irish into his blood. This year will stay inside him, enriching him and changing him and aiding his reading and thoughts in Irish (Ó Ríordáin 1982 [1954]: 87, my translation).

This is an exceptionally strong statement from a poet and linguistic virtuoso who is highly attuned to the "fine weave" of specific local ways of speaking. But I have heard similar sentiments expressed by urban gaeilgeoirí many times in my fieldwork, often in almost exactly the same terms.

There are several interesting things about Ó Ríordáin's statement. The almost ritual sacrifice of the self is also a humbling of the urban self in front of rural others in the sacred space of the Gaeltacht. The romanticism of the gesture is a revolutionary one, calling for the overthrow of the existing linguistic order. The act of personal transformation involves a double mimesis. The speech and thought of the gaeilgeoir is felt to become in many respects a mirror of the purer speech and thought of the Gaeltacht community. Thus transformed, he or she is to return to the center, transforming it in turn. This double mimesis is an example of what Taussig (1997) calls the magic of the state. It is the center, in the guise of the state, which invests the Gaeltacht with a sacred significance as a place of personal and national transformation. Although Ó Ríordáin came from the rural Gaeltacht, the discourse of linguistic purity is rooted in what is essentially an urban standpoint, listening in to local dialects from the outside. The novelist and Gaeltacht activist Máirtín Ó Cadhain criticized the discourse of purity precisely because it required the culture of the Gaeltacht to be static and "dead" - a living death as the victim of the state's magic. The atomized cultural and linguistic qualities celebrated by Ó Ríordáin are arguably the effects of poverty and the decline of the Irish language.

In such a discourse, Irish emerges as a very unusual example of an "official national language", where urban elites gain more credibility by achieving native-like proficiency in the speech of a single poor rural townland than they do by becoming exemplars of a new, "modern", "dialect-free" national standard.

The founder of the Gaelic League, Douglas Hyde, examining Irish culture in 1892, saw his fellow Irishmen living in a "halfway house" between Irish and English customs, language, and thought, having ceased being Irish without becoming English. In his famous lecture, "The Necessity for Deanglicising Ireland", Hyde advocated reviving Irish as the national tongue of what would thereby become a distinct and independent nation. Hyde reserved special scorn for the anglicization of personal and place names, and the ugliness of the new names created in a desperate attempt to imitate English ways.

The techniques of the self recommended by Ó Ríordáin are aimed as much at "deanglicizing" the self as at improving its Irish. Ó Ríordáin's article began with his confession that the speech of his native community, Baile Mhúirne, was "mixed", not with other dialects of Irish, but with English. Lurking within the discourse of 
linguistic purity is a purism which, like the purism of Richard Henebry, ultimately denigrates Gaeltacht speech as being fatally polluted with English borrowings and code-switching.

With this in mind we can consider an earlier piece of advice from Peadar Ua Laoghaire, on how to translate from English into Irish:

Read over the English matter carefully. Take all the ideas into your mind. Squeeze the ideas clean from all English froth. Be sure that you allow none of that oozy stuff to remain. English is full of it. You must also get rid of everything in the shape of metaphor. Take instead of it the true idea which the metaphor is intended to convey. When you have the ideas cleared completely of foreign matter, put them into the Irish side of your mind and shape them in the Irish language, just as you would if they had been your own ideas from the start. ${ }^{6}$

Ua Laoghaire suggests dividing one's mind into "English" and "Irish" sides as a bulwark against the oozy impurity of English-language expression. His injunction against metaphor represents an attempt to minimize or avoid mimesis - a mental quarantine at a border crossing.

The discourse of "the nation" aims at producing a deanglicized self purified of the taint of the urban center and modernity. While valuing discrete local voices (provided they pass the test of purity), these are valued less in themselves but as representatives of a generalized "national" essence. Ironically, such are often not the ideals of a great deal of Gaeltacht - based discourse. The set of discursive practices I term "personalist" ground linguistic value not in a generalized national past but in the here-and-now dynamics of local communities.

\section{Personation}

During my fieldwork (from 1992 to 1996) in Ráth Cairn, an Irish-speaking community of a few hundred people in Co. Meath, one of the first things that struck me about speech styles in Irish was the manner in which people imitated others in passing. These minimal quotations, usually only a single word or short phrase, are sometimes framed with phrases like mar a déarfadh $x$ (as x would say). Miniature performances, they simultaneously summon up an image of a third person and focus attention on the linguistic form of the quoted word or phrase.

As Lucy (1993, p. 94) observes, in direct quotation, "speakers [...] refer to particular utterance tokens, their particular form, their specific values as meaningful communication, and their actual effects as social action". Yet direct quotation always at least implicitly typifies the utterance-token:

\footnotetext{
${ }^{6}$ Peadar Ua Laoghaire, Papers on Irish Idiom, originally published in 1899. Quoted in Cronin (1996, p. 147).
} 
A unique utterance is not, by definition, a token because there is no corresponding type (the sign is only a sinsign in Peirce's 1932 framework). However, the moment a second utterance is produced which purports to copy or replicate that original utterance, it is no longer unique; a type has been created (the original utterance has been typified), and the original and its replicas must be regarded thereafter as tokens of a type - even though the reporter may be striving to articulate their contextual specificity and ultimately deny their status as tokens of types (Lucy, 1993, p. 120).

For Peirce $(1931-58,4.537)$, the token/type distinction is part of the trichotomy of tone, token and type (also called qualisign, sinsign, and legisign). In Peirce's philosophy all such distinctions are gradient rather than absolute, due to the principle of "synechism" (continuity). That is, tone, token, and type shade into one another. This has implications for the study of reported speech. More than just speech can be "reported". Voicing occurs on the tonic level, reporting speaking style and other gestural elements. Reported tone may be interpreted as an indexical icon of the speaker's entire habitus; thus direct quotation may, at least implicitly, characterize the original utterer, in a manner which goes far beyond the referential import of the speech-token itself.

Although performative imitation seems to be common in many societies, it arguably has not received the attention it deserves from linguistic anthropologists. Goffman (1974, p. 535) notes that "'taking off" was a well-developed recreational art" in the Shetland Islands of the 1960s. His general term for such behavior is "sayfors". In these,

...serious impersonation is not involved, since no effort is made to take anyone in.... At the center is the process of projecting an image of someone not oneself while preventing viewers from forgetting even for a moment that an alien animator is at work.

For Mitchell-Kernan (2001 [1972], p. 161), the African-American practice of "marking" is "a mode of characterization" which reports "what was said" - its semantico-referential meaning in Silverstein's (1976) sense - while foregrounding "the way it was said", i.e., its social-indexical (pragmatic) and iconic characteristics:

The meaning in the message of the marker is signaled and revealed by his reproduction of such things as phonological or grammatical peculiarities, his preservation of mispronounced words or provincial idioms, dialectal pronunciation, and, most particularly, paralinguistic mimicry.

Marking implicitly characterizes the quoted speaker in terms of his or her "background, personality, or intent", while also implicitly offering a metapragmatic commentary on the quoted speech:

If, e.g., some expressive feature has been taken as a symbol of the speaker's membership in a particular group, his credibility may come into question on these grounds alone. 
In some linguistic cultures, imitations of out-group social types seem to predominate. Basso (1979) analyzes Western Apache imitations of the Whiteman as serving to reinforce Apache solidarity and social norms by negatively characterizing the "Whiteman", while implicitly targeting deviant Apache behavior. Irish imitations tend to focus on local "characters", and more generally on old-fashioned speaking styles. When they do, they tend to be celebratory in spirit, even while dramatizing the "mispronounced words or provincial idioms" of their targets.

The use of direct quotation in Irish verbal art as a whole is grounded in these imitative acts, which I term personation. These brief imitations represent the simplest and most basic form of verbal performance. When introduced into conversation, they often indexically frame (i.e., "key", in Bauman's [1977] terms) a performative shift towards verbal art. In Silverstein's (2003, pp. 195-196) terms, an act of personation invokes a highly presupposed referent, the person imitated, but is at the same time a relatively "entailing" act, as a result of which "contextual parameters seem to be brought into being - i.e., causally and hence existentially entailed - by the fact of usage of the indexical (Sin)sign [= token] itself"' (Silverstein, 2003, p. 195). Personation is an extremely common feature of a mode of sociability that in Ireland is often referred to as "the crack", acting as the first step in the progression to heightened conversation and verbal art (Glassie, 1982).

Personation simultaneously calls attention to the social and personal provenance of particular language forms and makes social types out of the individuals quoted. It is, thus, a powerful metalinguistic tool in a community where different generations and social strata exhibit markedly different speaking styles. Personation carries an added social force in that it potentially calls to mind a whole range of social aspects of the person represented, implicitly suggesting an indexical link between these social and personal aspects and the elements of communicative style represented.

In its minimal form, personation is used in situations where both the audience and the person quoted are social familiars. Detailed background information about speakers and situations can be left unspoken. Even the identity of the quoted person can be left unstated. I noticed that one consultant sometimes mentioned the person's name only for my benefit, assistance that was clearly unnecessary for the other people involved in the conversation. In such situations quotation framing itself may be omitted, with the speaker merely gesturing toward another through use of particular words, dialect forms, or tone of voice, etc.

Although I was fascinated with this minimal, imitative form of personation, it was almost impossible to collect examples of it, because they were not regarded as "performance" and usually only took place in private conversation rather than in formal interview situations, radio talk, etc. People seemed almost unaware that they were doing it and I never got anyone to reflect on the practice per se. What people did reflect on were the speaking styles and personality of the persons quoted. This is in keeping with a semiotic ideology which identifies speech with "natural" aspects of speakers (see below for discussion).

Instead of trying to elicit personations or searching for explicit explanations of the practice, I occasionally tried to produce these forms myself. One time when a group of Ráth Cairn people was visiting Conamara, we were in a pub where a lottery was 
taking place, and I remarked that if a certain elderly Ráth Cairn woman were there, "she would be looking at the numbers". (bheadh sí ag breathnú ar na numbers). The response I got was "You have been here too long!" (Tá tú rofhada anseo). What made it work as a personation was the use of what people would term "her word" (numbers), spoken in her voice, plus her reputation as an enthusiast of any form of lottery, bingo, etc.

I found that the great majority of people personified were older people and "characters", especially people who had died in the last several years. I heard a few such people quoted so much that I felt like I knew them myself, even though they had passed away before my arrival in Ráth Cairn. Personation of older people was almost invariably affectionate, if not respectful, in tone. Often it highlighted antiquated speaking styles, especially the difficulties "the old people" (an seandream) had with English. Sometimes it was expanded into a full anecdote. For example, a (named, particular) Ráth Cairn man goes to Athboy (a nearby English-speaking town) and wants to buy some ballach (a type of fish), and asks the shopkeeper for "four bollockses". Máirtín Mac Donncha told me many stories like this, sometimes adding that it was a good thing to hear bad English spoken in Ireland! Here is an example of what Inoue (2003, p. 317) terms "inter-indexicality", an alignment of two systems of social indexicality in language: "accent" in English is used to construct "voice" in Irish. This celebration of "bad English" (droch-Bhéarla) also celebrates hybridity, by calling to attention the fact that "voice" in the two languages is related.

\section{Witticisms and personation}

Acts of personation are formally similar to, and often consist of, reports of witticisms. If I inquired about the persons being imitated, the responses I got often included examples of witty or memorable things these people had said, related in their voice and accent, usually accompanied by narrative explanations which set the scene for the piece of speech being reported. Likewise, in conversations I participated in or overheard, acts of personation often led into exchanges of reported witticisms, and thence to the production of brand-new witticisms as the conversational energy (perhaps aided by drink) took off. I did not find any commonly used generic term for witticisms in Ráth Cairn. Sometimes terms like "ceann maith" (a good one) were used to frame reported witticisms, as in "Bhí ceann maith ag $X$ an lá cheanna..." (X had a good one the other day...). In Glassie's (1982) fieldwork in 1970s Co. Fermanagh (an English-speaking community), he found a fairly elaborate metapragmatic terminology for the production and reproduction of witticisms. Glassie's informants termed them "bids", after a bid in a card game - potentially fallible pragmatic moves with relatively heavy entailments. The term 'bid' was used both for original and quoted witticisms. The pragmatics of witticism seem to have been identical to what I found in Ráth Cairn and in Gaeltacht areas more generally. A "bid" functioned as a witty or even hilariously ironic summation of the ongoing topic of conversation, and was ratified by fellow-participants through laughter or 
other forms of approbation, and often triggered a topic shift, thus becoming, at least for the time being, the "last word" on the topic.

As Ó Crualaoich (1998, p. 63) puts it, referring to Glassie's study:

'Crack' in this usage has the nature of humour and wit and flything ${ }^{7}$ or verbal 'besting' and when it has been in full swing for a while the people themselves report a further shift in the nature of the proceedings that raises it to a more intensive level again of communication. This shift is called the turn and results in the production of what they call the bid, an original utterance that caps a phase of the speech, the crack, the conversation, and that is perceived as having a note of both elegance and authority going with it. The 'bid' remains in the mind of the people present at the airneán [social gathering] and will be recalled on the next day and on the next occasion that an airneán assembles (Was not it well said by X last night', or didn't X put it nicely when she said... '). The bid is not a proverb or any other kind of ready-made speech formula. It is the creative, artistic response in speech to the vitality and intensity of communication of which it is itself an ornament and a temporary closure.

Witticisms represent and summarize stages in the development of the social interactions out of which they emerge. They are social in both inception and reception: they answer to immediate conversational needs and are ratified by being reproduced in the social group. As an ironic story-ending formula used by Joe Heaney went, "... and however well I told it tonight, may you not tell it half as well tomorrow night!"

The production of original witticisms, socially ratified by their reproduction by others, could be thought of as a form of self-personation, the creative entextualization of one's own voice. Like personation, witticisms circulate as tokens of value (Graeber, 2001) in the community. They are narratively linked to their "original utterers," carrying a bit of their immediate social essence. Note that witticisms circulate exactly like the more basic forms of personation - they are reproduced as quotations by others.

\section{Personation in verbal art}

Formally similar to reported witticisms are narratives (termed rannscéalta 'verse-stories' in Ó Morónaigh [2001]) which report the spontaneous utterances of poets, or those which report the ex tempore poetic utterances of ordinary persons in extraordinary situations. Reported poetic speech is often framed by narratives which set the scene for the poetic utterance itself, which functions as the culmination of and punch line for the narrative. As with "bids", poetic utterances entextualize ingenious responses to specific social situations. There is a tremendous amount of explicitly

\footnotetext{
${ }^{7}$ A dialect word meaning a verbal dispute, argument, contest.
} 
metapragmatic discourse about poetry and poets in the Irish tradition (cf. Ó hÓgáin, $1979,1982)$, most of which attributes a more or less supernatural degree of agency to poets with regard to the production of poetic speech. It is produced "without thinking", as a direct bodily emanation. Poets were sometimes said to have a special "vein of poetry" (féith na filiochta) which produced verse when agitated. A tradition going back to the mythical poet Aimirgín (Ó hÓgáin, 1982, pp. 30-32) compares smiths and poets; poems are thought of as especially durable speech. The term cruachaint (hard talk) is used for poetic language; cruachaint uses archaic forms and is alliterative and often lexically obscure. Such talk is held to be especially memorable and thus durable. It was said about the poems of Seosamh Ó Donnchadha, a contemporary Conamara poet, that "the cruachaint that was in them caused people to learn them by heart [...] and they would not easily forget them" (Ó Donnchadha, 1983, p. 28). Likewise, narratives depict the supernaturally efficacious utterances of ordinary people who are forced by extremes of situation or emotion into the production of poetic speech.

Poetic speech is thus (super-)naturalized as a direct corporeal emanation, typically empowered by the poet's relationship to the Otherworld. As the most semiotically entailing form of speech, poetry is felt to have a supernaturally augmented power of endurance and circulation. Irish folklore tends to rationalize all "talents" (buaidh) or "gifts" (dánta) as having Otherworldly origins. Similarly, the personal characters of poets, musicians, etc. are augmented stereotypically in folklore, which celebrates their ordinary and extraordinary deeds as well as their art.

This type of poetic lore is metapragmatic in that it presents tokens of poetic speech while contextualizing the poetic utterance and describing the effects its saying had on that context. Implicit in these stories is a use/mention distinction - the (often supernatural) effects of poetic utterances apply to their original utterance, not to their recontextualization by the here-and-now storyteller. This is not always the case, however, as poetic satire often explicitly (i.e., in the text of the poem itself) claims power based on its future dissemination. For example, a satire by Seosamh Ó Donnchadha proclaimed:

\section{Is an fhad is seasfas an teanga i measc Gaeil ChonamaralBeidh trácht $i$ ngach teaghlach faoin spóirt seo.}

And as long as the [Irish] language remains among the Gaels of Conamara/There will be talk in every house of this sport. (Ó Donnchadha, 1983, p. 102, my translation; cf. Denvir, 1989).

Analyzing a corpus of Icelandic legends about magical poets which strongly resemble Irish rannscéalta, Bauman (1992, pp. 132-135) suggests that the relationship between quoted poetic utterance and its narrative matrix is dialogic in Bakhtin's (1981, 1986) sense - the struggle for dominance between prose and verse acts as a constitutive feature of the textual structure of the whole. Thus, at a given point in the narrative, a section of verse may formally dominate its prose context, dictating its form and content, although at other points prose may predominate. Although the narratives in rannscéalta contextualize the verses they present, the verses tend to be 
dominant throughout, influencing and shaping the form of the narrative rather than the other way around. In Haviland's (1996) terms, the verse segment is transposed relative to the narrative, reflecting the deictic orientation of the poet, rather than that of the narrator:

In general, with the advent of the verse the narrator takes on the voice of the poet, serving as a kind of surrogate for him. While the verse is performed as [the poet] ostensibly performed it, with [the poet] at the deictic center of the utterance. . . the narrator is not making the verse but re-presenting it... (Bauman, 1992, pp. 133-134).

The Irish-language lyric song tradition - sometimes termed the sean-nós (oldstyle) tradition - contains examples of songs which have been transmitted in the form of spoken narrative alternating with sung verses. Thus, at least some of the song tradition takes the form of rannscéalta. But many exemplars of the tradition have made statements which, in effect, characterize the entire song tradition as consisting of sung verses accompanied by narrative 'stories' (Coleman, 1997, 1999).

\section{Lyric song as reported speech}

In the Irish-language lyric song tradition, 'songs' (amhráin) typically consist largely or entirely of first person utterance. Lyric song is often transmitted (and sometimes performed) along with spoken third-person narrative which sets the scene for the events of the song. Even when such narratives are absent, singers may insert (spoken) quotation frames around the sung lines, especially when the speaker changes from one verse or line to the next. ${ }^{8}$

In my fieldwork I found that many older people, singers and non-singers, took pains to point out, in effect, that the words to songs were the actual words of real people. They would object, for example, if a singer changed the gender of a song's protagonist to match their own gender. Violating the nature of song as transposed text is thus seen as a violation of tradition; "the authority of the verse as reported utterance predominates, becoming more forceful and more active than the [performance] context framing it" (Voloshinov, 1973, p. 121).

The narrative background to a song is often termed its údar (authority, authorship, cause, reason - cf. Ó Dónaill, 1977, p. 1296). Although typically representing the events surrounding a song's composition, údair may also encompass a song's performance history (Ó Laoire, 2002). Singers and other interpreters of the tradition often speak as if all songs have or originally had údair, even if they may have been lost in transmission. The singer Joe Heaney ${ }^{9}$ often maintained this, and he had a variety of other ways of metapragmatically construing songs as reported speech

\footnotetext{
${ }^{8}$ Some examples from early in the century are discussed by Freeman (1920-1921).

${ }^{9}$ Quotations from Joe Heaney (1978) are excerpted from interviews conducted by Esther Warkov, Fred Lieberman and Mike Seeger at the University of Washington, Seattle, in 1978.
} 
(Linzee, 1986; Coleman, 1997). He made much of the practice, in the Conamara dialect, of using the verb abair to describe or report singing. Speaking English (to Americans), he would insist that in Irish, you ask someone to "say a song" (abair amhrán) rather than to "sing a song". Abair is the verb used to directly report speech. The singer Liam Mac an Iomaire has mentioned that when he was young, children in his locality (in Conamara) would mock singers by saying aaaaaa agus a duirt sé, aaaaaa agus a dúirt sí ('aaaaaa and he said, aaaaaa and she said'). ${ }^{10}$ Here, they use abair (in the past tense) to frame "lines" consisting of nonsense sounds - a mocking imitation of the melismatically ornamented lines which are a prominent feature of Conamara singing style.

Joe Heaney used the proverbial phrase, "Abair amhrán, inis scéal" (say a song, tell a story) to emphasize the relationship between a song and its 'story'. In Bauman's terms, we could say that for Heaney, the dialogic relationship between lyric song and narrative is diagrammed by the relationship between these two metapragmatic verbs. Unlike abair, the verb inis (tell, relate, describe) cannot be used to frame directly reported speech. This figures a relationship between narrative as expressive of semantico-referential meaning, and verse, as carrying predominantly non-referential meaning. Thus, songs can carry "hidden" meanings:

Well you see, nobody ever asked you to sing a song. 'Abair amhrán'. Say a song. You know what I mean? Therefore, you are telling the story in a nice way. Because, when most of these songs were composed, the people could not express their views orally so they had to put it in verse (Heaney, 1978; my emphasis).

"Verse" has a potentially secret relationship to narrativity. The "secret" is that song, as direct discourse, does not necessarily reveal its own provenance - e.g., the identities of its speakers. The narrative "story" of a song may thus be kept implicit or have different referents at the same time. Thus, a love song in the form of a dialogue can be understood (via its narrative udar) as "really" being the poet's dialogue with a personified Ireland, and the song can carry political import. In Irvine's (1996), terms, there is more than one possible set of participant roles implicated in song performance. Thus, for singers like Joe Heaney, in song, one can "say" things without "telling" them. Parallel to this is Joe Heaney's insistence that Irish-language songs are difficult, if not impossible, to translate, while he had no problem with telling their accompanying stories in English. In Bauman's terms, for Joe Heaney, lyric song and narrative prose differ not only in their relation to referential content, but in their degree of entextualization - unlike prose, song cannot be entextualized in English without violating its fundamental nature.

The metapragmatic construction of song as relatively non-referential compared to narrative also constructs poetic utterance as bearing a relatively unmediated relationship to the (singing) self. Joe Heaney maintained that singers and their audiences must put themselves in the place of the songs' protagonists, feeling and seeing the

\footnotetext{
${ }^{10}$ Broadcast on Ráidió na Gaeltachta $8 / 26 / 03$.
} 
same things they felt and saw - singers must step into the protagonist's "I" (cf. Urban, 1989). Songs, as transposed utterance, are deictically centered around the perspective of their protagonists. As Haviland reminds us,

Each indexical sign projects a corresponding element of context, an elemental origo from which - by a further projection - an entire space may be seen to radiate (Haviland, 1996, pp. 280-281).

In the case of Irish lyric song, performers and their audiences are asked to inhabit this "space": In Joe Heaney's words,

...do I put myself in the man's name that this particular song was written about? Am I suffering the labors he did, can I go through that or have that picture before me; if I cannot follow that man, the journey he took, whether he was in bondage or slavery, I do not follow the song and I do not do it justice... (Heaney, 1978).

The act of pragmatic calibration (in Irvine's terms, lamination of participant roles) between the framework of here-and-now and that of the song's protagonist is a moral act for Joe Heaney. He maintained that the melodic form of the ornamented song lines was, or ought to be, based on the singer's emotional response to the projected "picture". Melodic form thus diagrams the relationship between singer and protagonist. ${ }^{11}$ The act of singing "personates" the singer as well as the protagonist. Joe Heaney emphasized that singing style is personal:

There's some people, they sing like somebody else you know, they imitate somebody and then, you know yourself, that's no good, you cannot do anything if you're thinking about what somebody else is doing, you cannot do anything right. It's like courting somebody else's girlfriend, with the two hands around her. You've got to do it your own way and let him do it his way (Heaney, 1978).

Thus, in singing, the production of performed text-in-context is not mere replication of prior text, but its transposition (Haviland, 1996), creating not only intertextual relations between song performance and other performances, including the protagonist's “original” utterance, but intertextual gaps (Briggs and Bauman, 1995) as well.

\section{Personation in other poetic genres}

In virtually the entire Irish-language poetic tradition, poetic discourse is figured as first-person utterance. In the pre-colonial period and thereafter until the final demise

\footnotetext{
11 There is a parallel here to Western Apache constructions of descriptive place-names as "the words of the ancestors", complete with moral exhortations to put oneself in the ancestors' place while contemplating places on the landscape (Basso, 1996).
} 
of the Gaelic political order, professional (bardic) poetry was often framed as direct utterance, either as dramatic lyric (Ó Buachalla, 1993) or as direct address to the patron (Carney, 1967).

Like the song tradition, several poetic genres feature dialogue or debate between poets and/or other protagonists. The agallamh beirte ('dialogue of two') is a representation of poetic conversation or debate, framed as ex tempore "argument in verse" (Ó hÓgáin, 1979, 1982). Examples of the genre can be found in the manuscript tradition (Ó Morónaigh, 2001, p. 15), often taking the form of philosophical dialogues between the poet and a personified Death, or between representatives of pre-Christian Ireland and their latter day heirs (Nagy, 1997). Historical epochs and even metaphysical principles are personalized and their speech (in verse) is recorded in this type of poetry.

Popular versions of agallamh beirte are produced with great regularity in the Gaeltacht, usually as humorous dialogue-skits which are sometimes acted out in front of audiences. These often feature stock characters who embody and represent particular social tendencies (the conservative farmer, the young person who scoffs at traditions, the avaricious priest, etc.). As with the more elevated forms of dialogue poetry, relatively abstract tendencies, principles, or social positions are embodied and literally given voice. In these dialogues, speaking style becomes extremely salient, as characters are identified by their way of speaking, which is implicitly identified with their social position and demeanor. This type of satire is intimately connected to the imitations discussed at the beginning of this article.

More seriously satiric poetry features the speech of the poet accusing and denouncing his or her victim, relating their crimes, and describing in a type of embedded virtual narrative, the punishments (to be) visited upon the victim. In the type of satire known as the fiach (hunt), the victim is portrayed as being chased throughout the locality, and sometimes beyond, through a succession of named places. Local people are named and quoted as they call for (and enact) punishment upon the victim. These poems, and more lighthearted variants, effectively map out a whole community, whose members are given voice (and whose voices are orchestrated) by the poet.

\section{First-person discourse in literary novels}

Given the prominence of first person lyric in Irish-language poetry, it may not be surprising that Séadna, the first modern Irish-language novel and "the first major prose work of the [Irish] revival" (O'Leary, 1994, p. 11) was written entirely in direct speech. Its author, Father Peadar Ua Laoghaire, sought to create a modern literary language literally by ventriloquizing caint na ndaoine (the people's speech):

There is not a single word in Séadna except for the word I heard from 'Peg' or from her mother or from my own mother. As I progress with the story, the speech comes to my memory (quoted in O'Leary, 1994, p. 12 , his translation). 
Although Ua Laoghaire's practice here mirrors that which I term personalist, his aims were purist in intent. His literary effort was in keeping with the dominant ideology of the Gaelic Revival at the turn of the 20th Century: that the Irish language was the nation's most effective "protective wall" against outside, corrupting influences:

There is enmity between the Irish language and [spiritual] infidelity. They cannot keep house together. If Irish is inside, infidelity must remain outside" (quoted in O'Leary, 1994, pp. 19-20).

Ua Laoghaire saw folklore both as a repository of "pure speech" and as a template for an antimodernist, and therefore pure, Irish literature. Séadna drew upon the genres and discourse of folklore, to the extent that critics sometimes denied that it was a novel at all (O’Leary, 1994, p. 105).

Similar accusations were made against Máirtín Ó Cadhain's (1949) novel, Cré na Cille (The Graveyard Clay). A native speaker of Irish, Máirtín Ó Cadhain was born in 1905 in the Conamara Gaeltacht. As a young man he collected folklore in his own community and worked as a schoolteacher (from 1926 to 1936). After moving to Dublin, he was hired as a lexicographer and translator of government documents (1947-1956), and was involved with official committees for coining Irish-language terminology. He became a highly regarded novelist, short story writer and essayist, and ended his life as Professor of Irish at Trinity College, Dublin. A typical nationbuilding intellectual of the type described by Benedict Anderson, he helped the Irish state assemble its own national language and recover its common heritage. But somewhat atypically for an Andersonian nation-builder, Ó Cadhain came from a poor rural background - from the very community whose language and culture were held to represent the true essence of Irishness and the model for a new national culture. Lacking the romantic distance of the typical nation-builder, Ó Cadhain was acutely aware of that other side of the Andersonian equation, the social and linguistic stratification which was only strengthened by Ireland's hard-won political independence. Cré na Cille was a merciless portrayal of the process of classformation in the Gaeltacht (and beyond).

Although he turned to Socialism late in his life, Ó Cadhan was a life-long member of the I.R.A., and was interned along with other leftists and republicans in the Curragh Camp, Co. Kildare, during the Second World War. It was there that he began work on Cré na Cille. A modernist novel, it set entirely in direct speech without any narrator or narrative voice. Its characters are corpses buried in a Conamara graveyard - a site which allegorically fused a vision of the contemporary Gaeltacht, a satirical portrait of the Irish state, and memories of his recent internment by that state in the Curragh Camp.

Ó Cadhain saw the representation of 'a person's own speech' as the key to his characters' psychology:

The most important thing in literature now is to reveal the human mind, something the camera cannot be pointed at. I mean a person's own speech. Speech is much stronger for doing that than giving stock phrases 
about his clothes, physical appearance, his language, the furniture in his house or the stage props, the features of the country, or the customs there. If it is a historical story, the history will tell you what your story's characters did, and psychology will help you a great deal to guess what led them to do those things. It's not what is on a person's skin [ie, what's on the outside] that is important, or even his skin itself, but the thing he is walking around with inside of his head. We know more about the stars of heaven than about what is happening inside that little shell next to you (Ó Cadhain, 1969, pp. 30-31, my translation).

Ó Cadhain makes a distinction between the direct speech of characters and narrative description - a distinction which parallels that made by Joe Heaney between poetic dialogue and narrative in the song tradition. In Cré na Cille, Ó Cadhain relies on the direct voice of his characters in dialogue as the only instrument with which to plumb their "depths". To make matters worse, Ó Cadhain deliberately exaggerates the degree to which his characters' speech is composed almost exclusively of clichés. The reader encounters only the characters' voices in dialogue with each other; characters are not even named except in their own or others' speech. This device powerfully highlights speech style, since it is by their speech styles that we know the characters. In Cré na Cille Ó Cadhain invented a new literary form, taking the form of an extended satirical agallamh beirte. In an event broadcast on Raidió na Gaeltachta, selections from the novel were read to an audience in Connemara, during the intermission of a singing contest. Hearing the characters' lines interspersed with the raucous laughter of the audience brought home the point that Cré na Cille is as much a work of popular verbal art as it is an avant-garde experiment. To demonstrate the similarities between Cré na Cille and the agallamh beirte verse form, I will now compare an example from each.

\section{2. 'The art of living'}

The graveyard in Cré na Cille is Ó Cadhain's vehicle for the transformation of caint na ndaoine (i.e., colloquial speech) into a new medium. His use of direct speech allows him to develop new forms within the "native" speech registers of he found around him, rather than creating new 'literary' registers. By doing this he brought the native registers into dialogue with each other, and with non-Irish fashions of speaking, letting them answer, rebut and debunk each other through his characters. An example of this dialogue is the meeting between the newly deceased Tomás Taobh Istigh and Nóra Sheáinín, whose daughter has married Caitríona's son. A corpse of shady social origins, Nóra is attempting her own post-mortem elevation into middle class respectability. Aided by the romantically befuddled Máistir Mór (the schoolmaster), Nóra has become 'literate' (the Master reads to her from his own grave), and 'cultured' (she uses fashionable English-language phrases, quotes from romantic novels and Abbey Theater productions, and throws in the odd word of French), even standing for election and founding a Rotary club in the graveyard. 
Nóra's newfound respectability is infuriating to Caitríona, who constantly harps on Nóra's shady past and the ignorance and poverty of An Gort Ribeach, Nóra's townland. But Caitríona's protestations have been ignored by the other characters until now: ${ }^{12}$

- - Eist, Thomas! That's the dote! Ní dhéanfaidh an 'tiff' sin le Caitriona ...

- - T'anam ón docks é "tiff"?

- - Ní dhéanfaidh an sciolladóireacht sin ach t'intinn a 'vulgarisáil.' Ní foláir domsa caidreamh a bhunú leat. Is mé oifigeach caidrimh chultúrtha na cille. Bhéarfaidh mé léachtaí dhuit ar "Ealaín na Maireachtála".

- - T'anam ón docks é, "Ealaín na Maireachtála ..."

- - Mhothaigh dream léarsannach againn anseo go raibh dualgais orainn dár gcomhchoirp, agus chuireamar Rótaraí ar bun ...

- - Is mór a theastaíos Rótaraí uaibh! Féacha mise ...

[NS] - - Hush, Tomás! That's the dote ! That tiff with Caitríona will not do... [TTI] - - Your soul from the Devil 'tiff'?

[NS] - - That abuse will only vulgarize your soul. I must establish relations with you [a pun]. I am the cultural relations officer of the graveyard. I will give you lectures on "The Art of Living".

[TTI] - - Your soul from the devil, "The Art of Living. .."

[NS] - - A far-seeing group of us here felt that we had a duty to our fellowcorpses, and we founded a Rotary...

[TTI] - - You certainly need a Rotary! I will see... (Ó Cadhain 1949:294, my translation)

Tomás does not understand Nóra's use of the fashionable English phrase 'tiff'. He interrupts her with an incredulous response, spoken in a homely cliche (your soul from the devil 'tiff'?). Nóra substitutes the Irish phrase sciolladoireacht (verbal abuse or scolding), but continues on with the English verb 'vulgarize', itself vulgarly gaelicized with the verbal suffix -áil. With this one word Nóra expresses her snobbish aspirations and reveals their source in an English-language discourse. Ó Cadhain's satire broadens with her next words which reveal her awkward command of bureaucratic jargon. Her offer to "establish relations" is an inadvertent sexual pun. "Ealaín na Maireachtála" (The Art of Living) is absurd in a graveyard setting as well as making much more sense in English than in Irish - Ealaín is often used derogatorily (to refer to drinking for example), and maireachtáil has the connotation of 'survival' as much as 'living'.

- - Go direach, Thomas. Féach thú fhéin! Ruabhoc romansúil thú a Thomais. Ba ea ariamh. Ach ní mór don románsaíocht stafóga an chultúir faoina cosa, lena hardú

\footnotetext{
${ }^{12}$ Lines in Cré na Cille begin with long dashes, indicating their coming into the foreground against the cacophony of voices in the graveyard, and frequently end with a series of dots, indicating latching or interruption by other speakers. Characters are not explicitly identified; for the sake of clarity I have identified them in my English translations as follows: NS = Nóra Sheáinín; TTI = Tomás Taobh Istigh; $\mathrm{D}=$ Dotie; $\mathrm{S}=$ An Scríbhneoir (The Writer); $\mathrm{CP}=$ Caitríona Phaidín.
} 
suas as an bhfód fiáin, agus Rí-Chorr comhéigneach na Fichiú hAiose ag ardchéimniú i gcluana gréine Chiúpaid a dhéanamh dhi, mar adeir Mrs. Crookshanks le Harry ...

- - Foighid ort, anois a Nóra chóir. Inseoidh mise dhuit céard aduirt Aoibheall Bhreoilleach le Snaidhm ar Bhundún i "Roiseadh na Fallainge" ...

- - Cultúr, Thomas.

- - T’anam ón docks, ab í Nóirín Sheáinín as an nGort Ribeach atá agam ar chor ar bith? ... Muise meastú a dtiocfaidh canuint mar sin ormsa i gcré na cille? Diabhal mé a Nóra go mbíodh caint bhreá Ghaelach agat sa sean-reacht! ...

- - Ná lig ort fhéin, a Nóróg, go cloiseann tú chor ar bith é.

- - Gug gúg, a Dotie! Gug gúg! Déanfaidh muid stroipín beag comhrá ar ball. Eadrainn fhéin, tá a fhios agat. Gug gúg!

[NS] --Certainly, Tomás. Look at yourself! You're a romantic roebuck, Tomás. You always were. But Romanticism needs the staffs of culture under her feet, to raise her up from the wild sod, to make her the cutting edge of the Twentieth Century dignifying herself in Cupid's sunny meadows, as Mrs. Crookshanks said to Harry ...

[S] - - Patience now, my dear Nóra. I will tell you what Aoibheall Bhreoilleach said to Snaidhm ar Bhundún in "The Tearing of the Cloak..."

[NS] - - Culture, Tomás.

[TTI] - - Your soul from the Devil, would that be Nóirín Sheáinín from Gort Ribeach? ... By dad do you think an accent like that will come over me in the graveyard's clay [cré na cille]? Devil me Nóra but you had fine Gaelic talk in the old days!...

[D] - - Do not let on at all that you hear him, Nóróg.

[TTI] - - Koo koo, Dotie! Koo koo! We'll have a bit of conversation in a while. Just between us, as you'd say. A pleasant little chat between us, you know. Koo koo!

(Ó Cadhain 1949:294, my translation)

Nóra's tremendously mixed metaphor brings together Yeatsian imagery and quotation from the cheap novels supplied by the Schoolmaster. 'Mar adeir $x$...' ' or 'Mar adúirt $x$...' ' (as x says/said) are very commonly used when quoting or attributing local witticisms. One would rarely find a 'Mrs. Crookshanks' quoted in this manner!

At this point An Scríbhneoir (The Writer) breaks in - Ó Cadhain's parody of hack 'folkloric' writers such as those who wrote for the state-sponsored Irish-language publishing project, An Gúm. The Writer begins to quote from his own 'masterpiece' - the characters' names ('Aoibheall Bhreoilleach' and 'Snaidhm ar Bhundún') translate as 'Frolicking Naked' and 'Knotted Bowels'.

Not recognizing her new accent, Tomás has been unaware of Nóra's true identity until The Writer addresses Nóra by name. Tomás comments on her changed accent, using the ambivalent word gaelach to approvingly describe her former ways. Gaelach means 'gaelic', i.e., 'pertaining to Irish-language culture or values', but also, 'backwards, homely, simple'. Nóra's friend Dotie breaks in urging her to ignore this insult, only to be greeted lewdly by Tomás. 
The conversation continues:

- - Bhí an cultúr orm ariamh, a Thomais, ach ní raibh tú $i$ ndon a fhiúntas a mheas. B'fhollasach dom é sa gcéad affaire de coeur a bhí ariamh agam leat. Marach sin b’fhéidir go ndéanfainn thú a ghreasacht beagán. Uch! Fear gan cultúr! Comradaí ba chóir a bheith a gcéile. Tiúrfaidh mé léacht duit, le cuidiú an Scríbhneora agus an Fhile, ar an ngrá platónach ...

- - Ní bheidh plé ar bith agam leat, a Nóra Sheáinín. M’anam nach mbeidh!...

- - Mo chuach ansin thú, a Thomais Taobh Istigh!...

- - Bhínnse ag cuimilt leis an uaisle tigh Neil Sheáinín ...

- - A chonúisín!...

- - Óra muise, is mór an spóirt iad na ceanna coimhthíocha sin, a Chaitríona. Bhíodh smáileog mhór bhuí ag iascach in éindigh le Lord Cockton i mbliana, agus chaithfeadh sí a raibh de 'feaigs' déanta. Chaithfeadh agus deirfiúr an tSagairt freisin. Bíonn siad i mboscaí móra i bpóca a treabhsair aici. Tá Mac Cheann an Bhóthair scriosta dhá gcoinneál léi. Tuilleadh diabhail aige, an bacach! Ach i nDomhnach duit, tá sise go gleoite. Shuigh mé isteach sa mótar abuil sí. "Gug gúg, a Neansaî" adeirimse...

- - Cré amh chaobach í t'intinn, a Thomáis dote, ach déanfaidh mé í a shua, a chumadh, a chruaghoradh agus a liomhadh nó go mbeidh sí ina soitheach álainn cultuir $\cdots$

- - Ní bheidh plé beag ná mór agam leat, aNóra Sheáinín. M’anam nach mbeidh. Fuar mé mo dhóthain diot. Ní bhiodh neart agam mo chois a chur isteach tigh Pheadar an Ósta, nach mbítheá istigh leis an tsáil agam, ag súdaireacht. B'iomaí pionta breá a sheas mé ariamh duit, ní dhá mhaíochtáil ort é!...

- - Ná lig ort fhéin, a Nóróg,...

- - Nár lagtar ansin thú, a Thomais Taobh Istigh! Go lige Dia mór do shaol agus do shláinte duit! Tabhair fúithi anois te bruite, faoi Nóirín na gCosa Lofa. Ag imeacht ag súdaireacht! An raibh tú tigh Pheadar an Ósta, a Thomais Taobh Istigh, an lá ar chuir sí an pocaide ar meisce? ... Go gcuire Dia an rath ort, agus innis é sin don chill...

[NS] - - I always had the culture on me, Tomás, but you could not appreciate its value. It was clear to me in my first affaire de coeur with you. Except for that I might have encouraged you a bit. Ugh! An uncultured man! Lovers should be comrades. I will give you a lecture, with the help of the Writer and the Poet, on platonic love...

[TTI] - - I will not have anything to do with you, Nóra Sheáinín. On my soul I will not!

[CP] - - Good for you Tomás Taobh Istigh!. . .

[TTI] - - I used to suck up to the gentry in Neil Sheáinín's [sic] house...

[CP] - - You little rubbish!

[TTI] - - Oh my, those foreign ones are great sport, Caitríona. There was a big lump of a blonde fishing with Lord Cockton this year, and she'd smoke all the fags ever made. She would, and the priest's sister would too. She keeps them in big boxes in her trouser pocket. Ceann an Bhóthair's son is destroyed keeping 
her supplied. Serves him right, the beggar! But I tell you, she is lovely. I sat in the car with her. "Koo koo, Neansai" I said ...

[NS] - - Your mind is raw lumpish [loutish] clay, Tomás dear, but I will knead it, shape it, fire it and polish it until it is a lovely vessel of culture...

[TTI] - - I will not have anything at all to do with you, Nóra Sheáinín. Upon my soul I will not. I have had my fill of you. I could not set foot inside Peadar's pub without you at my heel behind me, sponging. It's many's the fine pint I have stood you, not to begrudge you for it! ...

[D] - - Do not let on, Noróg...

[CP] - - Strength to you there, Tomás Taobh Istigh! May great God give you life and health. Give it to her piping hot now, to Nóirin na Cosa Lofa [Nóirín of the smelly feet]. Going sponging! Were you in Peadar's pub, Tomás Taobh Istigh, when she got the billygoat drunk? ... God prosper you, and tell it to the graveyard! (Ó Cadhain, 1949, pp. 294-295)

As Tomás rejects Nóra's offer of 'Platonic Love', Caitríona Pháidín cheers him on. Her approval of Tomás is entirely contingent on his laying low of her enemies her own sister Neil and Nóra Sheáinín. In the end, Tomás refuses Nóra's offer to make him into a lovely vessel of culture, which sets the stage for her uncrowning. Finally Nóra is unmasked as a drunkard and a sponger and her pretensions to 'culture' come to nought.

Joe Steve Ó Neachtain's (1986, pp. 35-40) agallamh beirte, “Ar Thóir Deontais" (Looking for a Grant) features a confrontation between a Gaeltacht mother and the civil servant who has denied her son a grant for speaking Irish. The civil servant relates to the mother how she gave her son an oral examination and concluded that he did not know any Irish at all. The humor of the piece revolves around the linguistic misunderstandings between the two. The civil servant reports the conversation she had with the son, but it becomes clear that the son, like the mother, heard the civil servant's "Standard" Irish words as English words:

[civil servant]:

Dúirt mise - 'Cad is ainm duit?'

Is níor fhreagair sé in aon chor!

I said - 'What is your name?'

And he [the son] did not answer me at all!

[mother]:

A dhiabhail, ní Cod is ainm dó!

it Baisteadh chomh maith leat féin é.

The devil [an expletive], his name is not Cod!

He was baptized just like you were.

Neither the son or the mother recognize the Munster dialect form, Cad is ainm duit. They both hear it as "Cod is ainm duit" - "Your name is a cod [a joke]". Likewise, they hear rothar as "roar" instead of "bicycle", and so on.

The son does not speak Irish at all, says the civil servant. She recommends that the family watch Trom agus Éadrom, a television program featuring light entertainment 
and a "bilingual" format featuring token use of Irish. The woman objects (using two assimilated English words) that that show is nothing but the host "scratching himself and blabbing in English" (á scraitseáil féin / Is é ag plobaráil i mBéarla). She says that the show's host is the type of person who is highly regarded and will get the best jobs in Ireland, and that the civil servant would never have gotten her job if she spoke Irish "from the cradle" (ón gcliabhán).

The civil servant responds, "But I have standard [Irish] and grammar, something that does not exist in the Gaeltacht" (Ach tá caighdeán agam is gramadach,/Rud nach bhfuil sa nGaeltacht). She accuses the mother and son of speaking "half-English" (leath Béarla). To this, the mother retorts that the civil servant would not speak Irish at all if it were not for her well-paying job.

In this poetic dialogue, and typically for the genre, the mother and son are cunning simpletons attempting to gain the upper hand in conflict with the outsider. Here, they do so by threatening her with retaliation from their local T.D. (her representative in the national Dáil). In the clientelist political system of Ireland - a political manifestation of personalism, where citizens gain access to state resources through face-to-face relationships with the state's local representatives - this is the only way to beat the Civil Service.

The conflict in Ó Neachtain's dialogue contrasts two attitudes to bilingualism. The mother, by her own reckoning, speaks "Irish" all the time, but has no problem with lacing her speech with unassimilated as well as assimilated loanwords from English. The civil servant, on the other hand, stands for a "bilingualism" where a pristine but artificial form of Irish is spoken, and where "standard [Irish] and grammar" are objects of value in an English-speaking world.

This is a conflict over possession. O Neachtain suggests that the discourse of the civil servant, by recognizing as genuine "language" only that which is regimented and formalized as "standard and grammar", dispossesses Gaeltacht people. The position of Irish is thus similar to that of Mexicano, an indigenous language of Mexico, where the purist discourse of "legitimo Mexicano" acts to devalue peasant speech. Jane Hill (1985, p. 735) refers to this purism as "linguistic terrorism", the voice of a Spanish-language discourse where "purist rhetoric joins other pressures in driving Mexicano into an underground, often secret, solidarity code".

For the hero of Ó Neachtain's miniature drama, as for Máirtín Ó Cadhain, bilingualism in Ireland is like "a cat and a mouse in a box". In an equal contest, English will have the upper hand (cf. Eckert, 1980). But in the wilfully hybridized speaking style that Ó Neachtain celebrates, the mouse has the cat in the box - English-language elements have been possessed and subordinated to an Irish-language discourse. Note the extreme contrast with the purism of an Ua Laoghaire, for whom Irish was an impermeable wall against corrupting influences, and the complete rejection of a superposed "standard".

In the 17th and 18th Centuries, as the colonial regime was consolidated in Ireland, Irish-language poets mocked their fellow Irishmen's adoption of English mannerisms by calling attention to the newfangled Englishisms (béarlachas) in their speech, manners and dress (Leerssen, 1996, p. 204). Now, in the late 20th century, Gaeltacht 
poets like Ó Neachtain defend the hybrid speech of their neighbors against the linguistic purism of an independent Irish state.

\section{Conclusion: metapragmatic function of personation and semiotic ideologies}

In Silverstein's (2003, p. 196) analysis,

Metapragmatic function ... is ideologically saturated; it relates ... the pragmatics of language use (e.g., in terms like "appropriateness to context" [indexical presupposition] and "effectiveness-in-context" [indexical entailment]) ... in terms of perhaps more fundamental frameworks, cultural agenda that bespeak human interests perspectivally caught up in social-institutional processes.

The metapragmatic function of personation is grounded in a semiotic ideology (which I term "personalism"), which takes speaking style to be a natural expression of a speaker's social persona, history, and genealogy. Such an ideology takes language use to be presupposing rather than entailing. Thus, personation is understood by its practitioners as a (presupposing) reflection of what's 'really there' more than as an (entailing or performative) act of characterization or stereotyping. Nor is it explicitly understood as an entailing or performative act which has the power to transform "ordinary" conversation into "crack". Witticisms, as a particular type of personation, are more self-consciously entailing, but still circulate as presupposing entities - cf. the use by Glassie's informants of the same term to denote both newly minted and quoted 'bids'.

Language use which is more explicitly construed as powerful and transformative tends to be dealt with in terms of a related set of semiotic ideologies which center on the nature of poets and poetry. Here, linguistic form is seen as a direct emanation from the poet's supernaturally enhanced being. Poetic speech is seen as immediate both in production (without thinking), its transmission (it is dangerous in that it is extremely durable and likely to be remembered and repeated by others), and in its semiotic form (for Joe Heaney, it gives access to the private world and point of view of others). For Máirtín Ó Cadhain, "a person's own voice" is both a tool for exploring their inner world and a political tool for resisting class stratification.

In Irish-language verbal art, maximal use is made of the construction of voice in direct discourse (as discussed above). Verbal art can be seen as an extension and deepening of everyday practices of quotation and voicing. One of the many social ends served by verbal art is thus the metapragmatic regimentation and revaluing of speaking styles. It comes as no surprise, then, that Gaeltacht verbal art plays an important role in resisting ideological assaults from without. Personation is thus a practice or meta-practice against which a whole set of genres are unified against other voicings of Irish. Briggs and Bauman (1995, p. 596) demonstrate that genres are brought into relation by pervasive and systematic "strategies of for creating intertextual relations". These strategies are grounded in more than simply linguistic life: 
[T]he roots of intertextual practices run just as deeply into social, cultural, ideological, and political-economic facets of social life as they do into the minutiae of linguistic structure and use.

I hope to have shown that personation is one such strategy - it enables a virtuoso like Ó Cadhain to bring local "voices" into dialogue with an entire range of fashions of speaking of local, national and international provenance, making concrete the degree to which these fashions of speaking are socially stratified along with values and sociopolitical orientation. The same thing happens on a much smaller scale in everyday imitations of local "characters". Personalism, as a semiotic ideology, gets an aura of common-sense givenness from its embodiment in a wide range of speech genres, and dialogically opposes those genres to others which are motivated by other discourses - the bureaucratic language of state and conservative nationalist homilies. Personalism locates linguistic value in a universe of known or knowable persons and social types, as opposed to other discourses which locate linguistic value in referential transparency or in an idealized national past.

The three discourses I identify here are ideal types, of course, and are not mutually exclusive. They often subsist in the same individual works or in the opinions and statements of a single individual. Ó Cadhain is exemplary here, because in some ways he both embodied and resisted all three discourses. Ó Cadhain's ambivalence possibly stemmed from an uncommonly clear realization that each discourse projects an idealized image of a wider community - locally bounded networks of rural people tied by relations of exchange, kinship, and obligation, a conservative nation insulated against change and outside influences, or a modernizing, centralized, technocratic state which has transcended its cultural roots. The suffocating political topology of Cré na Cille may reflect its author's intuition that all three of these things have come to pass in Ireland, and that none of these is enough.

\section{Acknowledgements}

I am grateful to Adi Hastings and Paul Manning, whose comments and suggestions were consistently helpful. I am also grateful to Laurel Sercombe at the University of Washington Ethnomusicology Archive for providing me with tape recordings of the interviews with Joe Heaney.

\section{References}

Agha, A., 2003. The social life of cultural value. Lang. \& Commun. 23 (3-4), 231-273.

Anderson, B., 1983. Imagined Communities. Verso, London.

Bakhtin, M.M., 1981. The dialogic imagination. In: Holquist, M. (Ed.) (M. Holquist \& C. Emerson, Trans.). University of Texas Press, Austin.

Bakhtin, M.M., 1986. The problem of speech genres. In: Emerson, C., Holquist, M. (Eds.), Speech Genres and Other Late Essays. University of Texas Press, Austin, pp. 60-102 (V.W. McGee, Trans.).

Basso, K.H., 1979. Portraits of the Whiteman: Linguistic Play and Cultural Symbols Among the Western Apache. Cambridge University Press, Cambridge. 
Basso, K.H., 1996. Wisdom Sits in Places: Landscape and Language among the Western Apache. University of New Mexico Press, Albuquerque.

Bauman, R., 1977. Verbal Art as Performance. Waveland Press, Prospect Heights.

Bauman, R., 1992. Contextualization, tradition, and the dialogue of genres: Icelandic legends of the kraftaskáld. In: Duranti, A., Goodwin, C. (Eds.), Rethinking Context: Language as an Interactive Phenomenon. Studies in the Social and Cultural Foundation of Language: No. 11. Cambridge University Press, Cambridge, pp. 125-145.

Bliss, A., 1981. The standardization of Irish. The Crane Bag 5 (2), 76-82.

Briggs, C.L., Bauman, R., 1995. Genre, intertextuality, and social power. In: Blount, B.G. (Ed.), Language, Culture, and Society: a Book of Readings. Waveland Press, Prospect Heights, pp. 567-608.

Carney, J., 1967. The Irish Bardic Poet. Dolmen Press, Dublin.

Coimisiún na Gaeltachta., 2002. Tuarascáil. An Roinn Ealaíon, Oidhreachta, Gaeltachta agus Oileán, Ríaltas na hÉireann, Baile Atha Cliath.

Coleman, S., 1997. Joe Heaney and style in sean-nós singing. In: Smith, T.M. et al. (Eds.), Blas: the Local Accent in Irish Traditional Music. Irish World Music Centre. University of Limerick, Limerick, pp. 31-52.

Coleman, S., 1999. Return from the West: a Poetics of Voice in Irish. PhD Thesis. University of Chicago, Department of Anthropology.

Coleman, S., 2003. The centralised government of liquidity: language and culture under the Celtic Tiger. In: Coulter, C., Coleman, S. (Eds.), The End of Irish History?: Critical Reflections on the Celtic Tiger. Manchester University Press, Manchester, pp. 175-191.

Cronin, M., 1996. Translating Ireland: Translation, Languages, Cultures. Cork University Press, Cork.

Daltún, S., 1983. Scéal Rannóg an Aistriúcháin. Teangeolas 17, 12-26.

de Bhaldraithe, T., 1992. Foclóir na Nua-Ghaeilge - forbairt agus fadhbanna. In: Byrne, C.J. et al. (Eds.), Celtic Languages and Celtic Peoples: Proceedings of the Second North American Congress of Celtic Studies, held in Halifax August 16-19, 1989 Halifax, Nova Scotia: D'Arcy McGee Chair of Irish Studies. St. Mary's University, Halifax, pp. 203-211.

Denvir, G., 1989. The living tradition: oral Irish language poetry in Connemara today. Éire-Ireland 24 (1), 92-108.

Eckert, P., 1980. Diglossia: separate and unequal. Linguistics 18, 1053-1064.

Errington, J., 1995. State speech for peripheral publics in Java. Pragmatics 5 (2), 213-224.

Errington, J., 1998. Shifting Languages: Interaction and Identity in Javanese Indonesia. Cambridge University Press, Cambridge.

Freeman, A.M., 1920. Songs from Ballyvourney, County Cork, with Irish texts and translations. J. Folksong Soc. Lond. 6 (23-24).

Glassie, H., 1982. Passing the Time in Ballymenone. Indiana University Press, Bloomington.

Goffman, E., 1974. Frame Analysis: an Essay on the Organization of Experience. Harvard University Press, Cambridge, MA.

Graeber, D., 2001. Toward an Anthropological Theory of Value: The False Coin of Our Dreams. Palgrave, New York.

Haviland, J., 1996. Projections, transpositions and relativity. In: Gumperz, J., Levinson, S. (Eds.), Rethinking Linguistic Relativity. Cambridge University Press, Cambridge, pp. 271-303.

Heaney, J., 1978. Interviews. University of Washington Ethnomusicology Archive, Seattle, Washington.

Hill, J., 1985. The grammar of consciousness and the consciousness of grammar. Am. Ethnol. 12, $725-737$.

Inoue, M., 2003. Speech without a speaking body: "Japanese women's language" in translation. Lang. \& Commun. 23, 315-330.

Keane, W., 2003. Semiotics and the social analysis of material things. Lang. \& Commun. 23 (3-4), 409-425.

Kiberd, D., 1996. Foras feasa an iarchoilíneachais. In: Ní Dhonnchadha, M. (Ed.), Nua-Léamha: Gnéithe de Chultúr, Stair agus Polaitíocht na hÉireann c. 1600-c. 1900. An Clóchomhar Tta, Baile Atha Cliath, pp. 20-40.

Leerssen, J., 1996. Mere Irish \& Fíor-Ghael. Cork University Press, Cork.

Linzee, J.I., 1986. Performance Variation in the Sean-nós Singing of Joe Heaney, M.A. University of Washington, Seattle. 
Lucy, J.A. (Ed.), 1993. Reflexive Language: Reported Speech and Metapragmatics. Cambridge University Press, Cambridge.

McManus, D., 1994. An Nua-Ghaeilge Chlasaiceach. In: McCone, K. et al. (Eds.), Stair na Gaeilge. Roinn na Sean-Ghaeilge. Coláiste Phádraig, Maigh Nuad, Maigh Nuad, pp. 335-445.

Mitchell-Kernan, C., 2001 [1972]. Signifying and marking: two Afro-American speech acts. In: Duranti, A. (Ed.), Linguistic Anthropology: a Reader. Blackwell Publishers, Malden, Mass, pp. 151-164 [1972].

Nagy, J.F., 1997. Conversing with Angels and Ancients: Literary Myths of Medieval Ireland. Four Courts Press, Dublin.

Ó Buachalla, B., 1993. In a hovel by the sea. The Irish Rev. 14, 48-55.

Ó Cadhain, M., 1949. Cré na Cille: Aithris i nDeich nEadarlúid. Sáirséal agus Dill, Baile Atha Cliath.

Ó Cadhain, M., 1969. Páipéir Bhána agus Páipéir Bhreaca. An Clóchomhar Tta, Baile Atha Cliath.

Ó Ciosáin, É, 1991. Buried Alive: A Reply to 'The Death of the Irish Language'. Dáil Uí Chadhain, Baile Atha Cliath.

Ó Crualaoich, G., 1998. Otherworld harmonies and heroic utterance: the fruits of the literary act among us. The Irish Rev. 23, 62-72.

Ó Dónaill, N., 1977. Foclóir Gaeilge-Béarla. Oifig an tSoláthair, Baile Atha Cliath.

Ó Donnchadha, S., 1983. Dánta Fhilí Bhaile na mBroghach. Cló Chois Fharraige, Indreabhán.

Ó Giolláin, D., 2000. Locating Irish Folklore: Tradition, Modernity, Identity. Cork University Press, Cork.

Ó Háinle, C., 1994. Ó chaint na ndaoine go dtí an Caighdeán Oifigiúil. In: McCone, K. et al. (Eds.), Stair na Gaeilge. Roinn na Sean-Ghaeilge. Coláiste Phádraig, Maigh Nuad, Maigh Nuad, pp. 745-793.

Ó hÓgain, D., 1979. The visionary voice: a survey of popular attitudes to poetry in Irish tradition. Irish Univ. Rev. 9 (1), 44-61.

Ó hÓgáin, D., 1982. A File: Staidéar ar Osnádurthacht na Filíochta sa Tradisiún Gaelach. An Gúm, Baile Atha Cliath.

Ó hÓgáin, É, 1983. Téármaí teicniúla sa Ghaeilge: caighdeánú agus ceapadh le céad bliain anuas. Teangeolas 17, 27-33.

Ó Laoire, L., 2002. Ar Chreag i Lár na Farraige: Amhráin agus Amhránaíocht i dToraigh. Cló IarChonnachta, Indreabhán, Conamara.

ÓMorónaigh, S., 2001. Agallaimh na hÉigse: Cioradh agus Cnuasach. Comhlachas Náisiúnta Drámaíochta, Camus, Conamara, Co. na Gaillimhe.

Ó Murchú, M., 1984. Smaointe faoi chaighdeánú na Nua-Ghaeilge. Teangeolas 18, 14-19.

Ó Murchú, S., 1978. An Caighdeán Oifigiúil tar éis fiche bliain. Éigse 17, 361-370.

Ó Neachtain, J.S., 1986. Fead Ghlaice. Cló Iar-Chonnachta, Indreabhán.

Ó Ríordáin, S., 1982 [1954]. An Ghaeltacht agus Fairsingiú na Teangan. Comhar 41 (5), 86-88 [1954].

Ó Siadhail, M., 1981. Standard Irish orthography: an assessment. The Crane Bag 5 (2), 71-75.

O'Leary, P., 1994. The Prose Literature of the Gaelic Revival 1881-1921: Ideology and Innovation. Pennsylvania State University Press, University Park, PA.

Peirce, C.S., 1931. Collected Papers. Harvard University Press, Cambridge, MA.

Romaine, S., 1994. Language in Society: an Introduction to Sociolinguistics. Oxford University Press, Oxford.

Silverstein, M., 1987. Monoglot 'Standard' in America, in: Working Papers and Proceedings of the Center for Psychosocial Studies (13). Center for Psychosocial Studies, Chicago.

Silverstein, M., 2000. Whorfianism and the linguistic imagination of nationality. In: Kroskrity, P.V. (Ed.), Regimes of Language: Ideologies, Policies, and Identities. In: School of American Research Advanced Seminar Series. School of American Research Press, Santa Fe, NM, pp. 85-138.

Silverstein, M., 2003. Indexical order and the dialectics of sociolinguistic life. Lang. \& Commun. 23 (3-4), 193-229.

Taussig, M.T., 1997. The Magic of the State. Routledge, New York.

Urban, G., 1989. The "I" of discourse. In: Lee, B., Urban, G (Eds.), Semiotics, Self, and Society. Mouton de Gruyter, Berlin, pp. 27-51.

Voloshinov, V.N., 1973. Marxism and the philosophy of language, in: Matejka, L., Titunik, I.R. (Trans.). Harvard University Press, Cambridge, MA. 